\title{
BSE risk and the use of meat and bone meal in the feed industry: perspectives in the context of relaxing control measures
}

\author{
Christian Ducrot ${ }^{1}$, Mathilde Paul ${ }^{2}$, Didier Calavas ${ }^{3}$ \\ 1 Épidémiologiste, INRA, UR346 Épidémiologie animale, 63122 Saint-Genès-Champanelle, France \\ 2 Épidémiologiste et géographe de la santé, Université de Toulouse, INP-ENVT, INRA, UMR 1225, IHAP, 31000 Toulouse, France \\ 3 Épidémiologiste, ANSES Lyon, 69000 Lyon, France
}

\begin{abstract}
Plus de quinze ans nous séparent aujourd'hui de la crise de la vache folle, déflagration majeure qui ébranla plusieurs piliers de nos sociétés contemporaines : les rapports entre science, politique et intérêts économiques, les formes d'intensification des productions animales, la confiance dans les produits alimentaires. Pour la revue NSS qui se focalise sur les liens complexes entre natures, sciences et sociétés, cette crise fut emblématique. Cet article et le commentaire qu'il suscite permettent de saisir les tensions encore aujourd'hui profondes liées à la normalisation de cette crise. Plus de dix ans après l'interdiction totale des farines animales, mesure à caractère symbolique dont on peut douter de l'efficacité en termes de gestion des risques, la Commission européenne propose un plan visant à utiliser en alimentation animale des protéines d'animaux transformées (PAT). À n'en pas douter, elles sont très différentes des farines animales et, selon les experts, leur utilisation permettra d'économiser de précieuses ressources énergétiques et environnementales. Le consommateur et le citoyen devraient en percevoir les avantages. Et pourtant. Les incertitudes sur la mise en œuvre du plan, les questions concernant l'effectivité des contrôles mais aussi la réaffirmation de la rationalité instrumentale qui gouverne les productions animales montrent que l'invention des PAT n'a rien d'évident.
\end{abstract}

La Rédaction

\section{Keywords:}

health; risk; BSE;

geography;

epidemiology

\section{Mots-clés :}

santé ; risque ; ESB ; géographie ; épidémiologie

\begin{abstract}
The paper presents an insight from epidemiology and geography on the BSE risk. The epidemic declined sharply following the ban of meat and bone meal in ruminant feed. BSE cases born after the ban and reinforced measures were due to cross-contamination between feed for monogastrics and feed for ruminants at the feed factory and on farms. Cross-contamination is difficult to control in the feed chain, particularly because contaminated material can infect cattle at very low doses. Designing separate feed processing lines or dedicating factories to ruminants is an efficient strategy, but is not economically feasible in the regions with low animal density. So, changes in control measures should target both the feed industry and farmers, and take into account the difficult economic context that limits the industry's ability to adopt the most effective solutions to prevent cross-contamination.
\end{abstract}

Corresponding author: C. Ducrot, ducrot@clermont.inra.fr 
au regard de la faible valeur ajoutée. Il résulte de ces travaux qu'un assouplissement des mesures de contrôle du risque devrait tenir compte du contexte économique délicat pour la mise en œuvre de mesures efficaces de maîtrise des contaminations croisées, et cibler également les risques à la ferme.

Bovine Spongiform Encephalopathy (BSE) is a zoonotic disease that spread in cattle in the 1980s and 1990s, with serious economic consequences for the agrifood sector and posing a potential threat to public health. In the early stages of the epidemic, the use of Meat and Bone Meal (MBM) in animal feed was identified as the major route of cattle infection (Wilesmith et al., 1991). This led policy makers to design a set of control measures that were adapted over time, progressively resulting in the total ban of MBM in feed for all farm animals. Now that the BSE epidemic has decreased dramatically and almost disappeared, there is heavy pressure from different parties to relax these risk control measures, including the total feed ban, as announced in the second Transmissible Spongiform Encephalopathies (TSE) road map of the EU (European Commission - DirectorateGeneral for Health \& Consumers, 2010). However, to prevent another TSE crisis, a sustainable and relevant surveillance and control system must be established.

The ban on MBM in ruminant feed implemented in July 1988 in the UK, July 1990 in France and June 1994 in the European Union had a strong effect on decreasing the epidemic, but it was not fully effective in controlling the disease. The cross-contamination of feed for cattle with feed intended for monogastric species still containing MBM was thought to be a residual source of infection. To better control the risk, complementary measures were enforced (Tab.1), including the ban of cadavers and specified risk materials (SRM) from MBM used in pig and poultry feed, high pressure cooking of MBM, and most recently the total ban of MBM in feed for all farm animals. Cross-contamination may have occurred at various points in the feed chain, from the level of MBM factories down to farms. The French cattle industry includes more than 8 million adult cows fed within different feeding systems, and it was deeply affected by the BSE epidemic for two decades. Drawing from diverse studies of the French cattle industry, the present paper aims to analyse how BSE risk spread in the cattle population through the food chain. The analysis relies on an interdisciplinary approach that combines epidemiology with geography ${ }^{1}$. Epidemiological studies helped to

\footnotetext{
1 Various epidemiological and modelling studies were conducted on BSE in France (collaboration between ANSES Lyon, INRA UR346, and Ministry of Agriculture) and their results are refered to in this paper. A complementary geographical approach to the feed industry also was carried out by Mathilde Paul during her master degree research in Health Geography, done at INRA UR346. It was based on data from the epidemiological studies, the literature and interviews of field workers from different professions.
}

identify where cross-contaminations took place along the food chain, and to assess the impact of the different control measures that were taken to control the BSE epidemic. The geographical approach contributed to an understanding of the organisation and constraints of the feed industry, as well as how cross-contaminations were handled along the feed chain process. The paper draws on the lessons learned from the past to propose advice for the relaxing of control measures currently under consideration by the European Union.

\section{Epidemiological studies}

\section{Epidemiological analysis of the routes of infection for BSE cases born after the feed bans}

In the early stages of the BSE epidemic, epidemiology played an essential role in the understanding of the sources and routes of cattle infection. In the early 1990s, it became evident that the ban on MBM in ruminant feed, which had been implemented in July 1988 in the UK, was not totally effective in controlling the disease as cases began to occur in animals born after the feed ban (BAB). Different studies were carried out to investigate the source of infection of these animals. In 1993, a casecontrol study was initiated in the UK to investigate the possibility of horizontal and maternal transmission (Hoinville et al., 1995). This study indicated that neither maternal nor horizontal transmission could account for the majority of $B A B$ cases. Furthermore, within-herd incidence has decreased over time in parallel with UK national incidence, only a relatively small number of herds have had a large number of cases, and consequently there is no evidence of horizontal transmission of BSE. The low within-herd incidence of herds affected with BSE is further evidence that horizontal transmission has scarcely occured, if at all.

An analysis of the geographical variation in incidence provided the first explanation of BAB cases in the UK. A study showed a statistically significant correlation between the cumulative incidence of BAB cases and the ratios of both cattle to pigs and cattle to poultry (Wilesmith, 1996). The conclusion was that an accidental cross-contamination occurred between pig and poultry feed which still contained MBM and cattle feed in which MBM was banned. Such a cross-contamination was assumed to have occurred at various stages of the feed chain: either at the feed factory, during the transport of feed to farms, or on the farm if both cattle and pigs or poultry were raised there. The potential for cross-contamination is heightened by the capacity of low-dose 
exposure to cause infection; in an oral-exposure study it was shown that cattle could become infected by as little as $1 \mathrm{mg}$ of brain homogenate (Wells et al., 2007).

In France, the ban of MBM in cattle feed went into force in July 1990 and the first BAB case was detected five years later, i.e. the approximate equivalent of the average incubation time. A statistically significant relationship between pig density and the number of $\mathrm{BAB}$ cases has been shown in France (Abrial et al., 2005) as well as in other countries, including Northern Ireland, Switzerland and Spain (Allepuz et al., 2007; Denny \& Hueston, 1997; Doherr et al., 2002; Schwermer \& Heim, 2007), supporting the hypothesis of cross-contamination of cattle feed with feed intended for pigs and possibly poultry. To analyze in greater detail at which stages of the feed chain cross-contaminations may have played a role in the spread of BSE in France, a spatial study of feed factories was carried out that confirmed the use of MBM in monogastric feed as a risk factor for BSE (Paul et al., 2007). In parallel, a case-control study at the farm level (Jarrige et al., 2007) demonstrated that the use of compound feed for young cattle, and the presence of poultry operations on farms, using compound feed, were risk factors for BSE, thus providing further evidence of the role of compound feed in the risk of BSE. These results indicate that the cross-contaminations might have occurred either at the feed factory level, during shipment, or at the farm level.

A ban of SRM, which contain the most infectious material from infected cattle carcasses, in animal feed was implemented in France in July 1996 (Tab. 1). This did not totally remove the feed-borne risk of exposure, and five years later the first BSE case born after this second ban (BASB) was detected. It was found from the spatial analysis of BSE risk (Ducrot et al., 2005) that BASB cases had a similar spatial distribution as that of the BAB cases born just before the SRM ban, suggesting a common source of infection. Similarly, Schwermer \& Heim (2007) found that the feed-borne source was the most likely route of infection in Switzerland for cases born after the ban of SRM in MBM. In Germany, the main routes of transmission are considered to be cross-contaminated ruminant compound feeds and milk replacers which contain animal fat (Clauss et al., 2006). Milk-replacers could legally contain animal-derived fat up to the year 2000 in Germany, and it is possible that infectious material either survived the rendering process or entered milk replacers through the use of unrefined fats (Kamphues et al., 2001). However, there is no experimental evidence showing that tallow from an infected cow contains infectivity and the causal link between milk-replacers and BSE infection thus remains an hypothesis.

In conclusion, epidemiological evidence from several countries suggest that the feed-borne source related to MBM is the only substantiated route of infection, although it is not possible to exclude maternal transmission or milk replacers as the source of some infections. Most if not all of the cases born after the ban on MBM in ruminant feed and the second ban of SRM in feed for farm animals have arisen due to continued exposure to contaminated feed. Cross-contamination also seems to have occurred at the feed factory level as well as on farms where both cattle and monogastric species are raised.

\section{Modelling the BSE epidemic and assessing the effect of control measures}

The results of the above mentioned analytical epidemiology and spatial studies were confirmed by epidemiological analyses and modelling studies on the temporal trend of the BSE epidemic that aimed to estimate the evolution of BSE risk over time (Calavas et al., 2007). It currently is impossible to directly estimate the exposure of cattle to the agent of BSE because the agent cannot be sought or analyzed in feed. Estimating exposure therefore is done indirectly and relies on the analysis of the number and characteristics of cases detected by surveillance systems. More precisely, by studying the number of cases detected year after year, one may derive the risk of infection according to successive birth cohorts and therefore assess the effect of successive control measures.

This exercise was based on statistical analyses and mathematical modelling; it was particularly difficult for a set of reasons related to the characteristics of the disease and surveillance parameters. In terms of the former, the age at which the disease becomes detectable is higher than the age at which most animals die or are slaughtered, the time between infection and detectability is poorly documented, and until present no diagnostic test has been developed for live cattle. With regard to surveillance, systems can change dramatically over time, as shown by the example of France. From December 1990 to June 2000, the French surveillance system was limited to the clinical surveillance of adult cattle showing symptoms compatible with BSE. The efficiency of this system was weak and biased according to the region and the farm production type (e.g. dairy $v$ s beef) (Ducrot et al., 2003). A comprehensive BSE surveillance system was introduced in June 2001, and includes today clinical surveillance as well as the testing of all slaughtered animals aged four years and over or dead animals aged two years and over.

The efficiency of the 1990 control measures is impossible to estimate by analysing the surveillance data due to the low number of cases detected and born before the end of 1990 ( 38 such cases detected until $1^{\text {st }}$ September 2011). Modelling consequently was the only way to estimate BSE trends, notably during the first decade of the epidemic in France. Based on the 103 BSE cases detected in France between 1991 and June 2000, a back-calculation 
Table 1. Main control measures of BSE in France.

\begin{tabular}{|c|c|c|c|}
\hline Topic & Measure & Date & Regulation origin \\
\hline \multirow[t]{5}{*}{ Trade restrictions } & $\begin{array}{l}\text { Start of trade restrictions for live cattle and bovine } \\
\text { products from the United Kingdom (UK) }\end{array}$ & July 1989 & European \\
\hline & Ban of MBM import from the UK for use in feed & August 1989 & French \\
\hline & \multirow[t]{2}{*}{ Total ban of live cattle and bovine products from the UK } & $1989-2006$ & French \\
\hline & & March 1996 & European \\
\hline & Ban of MBM in cattle feed & July 1990 & French \\
\hline \multirow{3}{*}{$\begin{array}{l}\text { Use of meat } \\
\text { and bone meal } \\
(\mathrm{MBM})\end{array}$} & Ban of MBM in ruminant feed & June 1994 & European \\
\hline & $\begin{array}{l}\text { High pressure cooking of } \mathrm{MBM}\left(133^{\circ} \mathrm{C}-20 \mathrm{~min}-3 \text { bars- }\right. \\
\text { particle size less than } 50 \mathrm{~mm})\end{array}$ & July 1996 & European \\
\hline & Ban of MBM in feed of all farm species & December 2000 & European \\
\hline $\begin{array}{l}\text { Use of specified } \\
\text { risk materials } \\
(\mathrm{SRM})\end{array}$ & $\begin{array}{l}\text { Removal and destruction of SRM (list of SRM } \\
\text { was adapted progressively) }\end{array}$ & $\begin{array}{l}\text { August } 1996 \\
\text { October } 2000\end{array}$ & $\begin{array}{l}\text { French } \\
\text { European }\end{array}$ \\
\hline $\begin{array}{l}\text { General } \\
\text { regulation TSE* }\end{array}$ & $\begin{array}{l}\text { Adoption of Regulation EC 999/2001 laying down rules } \\
\text { for the prevention, control and eradication of TSEs }\end{array}$ & May 2001 & European \\
\hline
\end{tabular}

* Regulation EC 999/2001 defines minimum requirements for surveillance of transmissible spongiform encephalopathies (TSE) but each member state can add complementary measures, provided that it does not hinder trade within the Community and introduces no distortion of competition between member states.

model was used to reconstruct the temporal trend of BSE infections (Supervie \& Costagliola, 2004). The main result of the model is that from 1987 onwards, the pattern of the epidemic was a coherent reflection of the implementation of control measures. Imports of British MBM increased sharply in the late 1980s, which possibly explains the rise in the number of infections between July 1987 and June 1990. Initial control measures, such as the French embargo on British MBM (August 1989), the embargo on live cattle imports and the ban on MBM in cattle feed (July 1990), could explain the decrease of the estimated risk between July 1990 and June 1993. Feed cross-contamination and recycling of infectious material within the feed industry might explain the rise observed between July 1993 and June 1996. The decrease of the number of estimated infections after June 1996 is likely explained by the measures taken in 1994 (MBM ban extended to feed for all ruminant species) and more importantly in 1996 (ban on SRM and cadavers in MBM processing). This decrease was confirmed in an update of the model in 2005 (Supervie \& Costagliola, 2005).

The comprehensive BSE surveillance system with rapid tests that has been implemented in France since June 2001 made it possible to study the relative exposure of the most recent birth cohorts using age-period-cohort statistical models (Sala et al., 2009). The results of this study were in agreement with those of the back-calculation model. The decline of the BSE epidemic in recent years could have originated in the implementation of the ban on the use of MBM for all ruminants in 1994, then been reinforced by the measures taken in 1996 resulting in a decrease in BSE exposure from the birth cohort July 1995-June 1996, the risk being almost null for the cohorts born after 1999. It is therefore very difficult to assess the effect of the last two control measures (prohibition of the use of SRM in 1996 and total MBM ban in 2000) which were implemented when the disease already was in a trend of strong decline. Results observed in France are in agreement with those observed in other European countries (Ducrot et al., 2010).

To summarize, the analysis of the trend of the BSE epidemic showed a clear decline of the risk of BSE following the first feed ban prohibiting MBM for cattle but the risk was not totally removed. After the implementation of complementary measures, especially a ban on SRM in MBM and a reinforced sterilization of MBM, the risk continued to decrease and became almost null at the same time that the ban prohibiting MBM was extended to all 
farm animals. While the models and statistical analyses indicate that each of the successive measures could have contributed to controlling the risk of BSE, the analysis of their respective effects is not straightforward and one must be very careful about drawing conclusions for several reasons. First, the mathematical models rely on strong hypotheses regarding the distribution of age at infection, the incubation period, and the level of under reporting of BSE cases during the first decade of surveillance. Second, it is not possible to assess when and to what extent each of the control measures actually were implemented. Third, the relationship between a variation in the risk of BSE and the implementation of a control measure cannot be considered to be causal with absolute certainty and could be at least partly circumstantial.

Even if the risk of BSE is now very low, it is not null. Up to the end of $2009^{2}, 60$ cases of BSE were detected in the European Union, that were born after the total feed ban of MBM in animal feed; at that date, the youngest case was born in 2005, 5 years after the ban. Furthermore, two atypical forms of BSE were detected at a very low prevalence (around one case per million cattle tested) (Biacabe et al., 2008). Those forms are probably not linked to the BSE epidemic and might remain present in the future, and at least one of them might be transmissible to Humans (Beringue et al., 2008).

\section{Insight from geography on the feed industry}

Following the epidemiological studies, which indicated that the feed industry may not have managed crosscontaminations in an optimal manner, complementary research was carried out in 2006 using a geographical approach. This work aimed to understand what impeded the effective management of cross-contaminations in the feed industry. The underlying hypothesis was that the different local contexts of feed processing factories contributed to varying capacities to manage crosscontaminations. Quantitative data collected from March 2004 to June 2005 by the Ministry of Agriculture (Direction générale de l'alimentation) in 1014 feed factories in France (Paul et al., 2007) were used to describe the local contexts of feed production in France. In addition, qualitative data were collected in Bretagne in June 2006. This work included interviews carried out with 5 feed producers, 2 renderers, 3 technicians from the Chamber of Agriculture, as well as veterinary practitioners and cattle farmers. The interviews dealt with the local economic context, the conditions under which MBM was incorporated into cattle feed, and the management of crosscontaminations in factories.

\footnotetext{
2 http://ec.europa.eu/food/food/biosafety/tse_bse/ monitoring_annual_reports_en.htm, consulted February, 20,
} 2012.

\section{Historical background on the use of MBM in the feed industry}

In France, the production of animal compound feed grew considerably during the post-war boom years: from less than one million tons produced in 1950, production reached more than 15 million tons in the 1980s (Quinqu, 1989). The growth in demand for white and red meat products resulted in the increased use of compound feed (Dronne, 2003). In particular, dramatic increases in pig and poultry production played a key role in this continuous expansion (Diry, 1985) in France because these species were fed largely with compound feed. As a result, higher pig and poultry production translated directly into the increased use of compound feed (Hasha, 2002). The increase in the volume of manufactured compound feed produced in France slowed in the 1990s and then stopped; production levels have remained stagnant since 2000 (Fig. 1). This is partly due to a lack of further improvement of the feed conversion ratio (i.e. the quantity of feed needed to produce a given quantity of meat, eggs or milk) since the 1990s (Dronne, 2003), and the flagging demand for livestock products in France and Europe (Rude \& Meilke, 2000).

The increase and intensification of livestock farming, which started in the middle of the $20^{\text {th }}$ century in France, resulted in a strong rise in demand for proteins in animal feed. The export embargo on soybean enforced by the USA in 1973 following a drop in production (Mouillet, 2003) highlighted Europe's vulnerability and lack of autonomy with regard to protein sources for animal feed (Lapierre \& Pressenda, 2002). Given its nutritional characteristics, MBM was a convenient substitute for other protein sources, including soybean (Dronne, 2003). The increasing use of MBM in animal feed was at the time a means of making the most of animal by-products while managing an increasing need for protein ingredients. As its price was driven by the price of soybean, MBM was a competitive ingredient for feed formulation only at specific times and on specific markets. It was used most widely in feed for poultry and pigs with a rate of up to $7 \%$ in feed for turkeys (Enjalbert, 1996). In contrast, it was not used systematically for cattle feed and when it was, the proportions were much lower.

\section{Organization of feed production chains: variations in local contexts}

With the growing global demand in the 1950s, the French feed industry became a European leader (Fefac, 2009). In 2010, more than 21 millions tons ${ }^{3}$ of animal feed were produced in France, of which 5.03 million tons

\footnotetext{
3 http:/ /www.nutritionanimale.org/1-syndicat-de-lanutrition-animale/120-fabricants-pour-l-elevage/184-enfrance.aspx, consulted May, 3, 2013.
} 


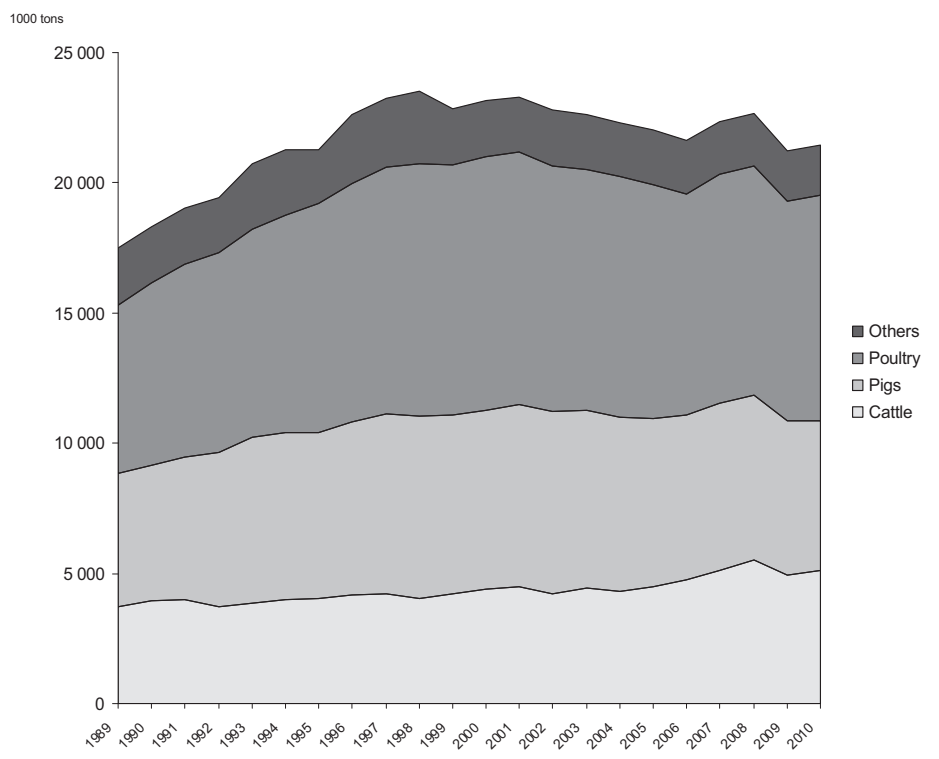

Fig. 1. Annual compound feed production in France by animal species, from 1989 to 2010 (source of data: Fefac, 2009).

were for ruminants and 14.38 for pigs and poultry. Regardless of the size of a company, the value-added rate for the animal feed industry is low in comparison with other food-industry sectors (Agreste, 1995), and the optimum management of production costs therefore is necessary. For animal feed, the price of the raw materials used as ingredients represents $80 \%$ to $85 \%$ of the production cost (Brookes, 2001; Quinqu, 1989).

Compound feed is manufactured from a mixture of raw materials designed to reach the specific requirements of the targeted livestock (Brookes, 2001). These raw materials come from a wide variety of sources (Fefac, 2009) and the price of one ingredient relative to another is of key importance for feed formulation. Feed manufacturers modify feed composition on a daily basis to take into account fluctuations in the price of raw materials, substituting ingredients for each other depending on the lowest instant market price (Dronne, 2003). The compound feed industry has become capital-intensive in recent years, making use of complex manufacturing machinery with a high level of technology (Fefac, 2009). In this context, advanced methods are used to formulate feed in response to demand from livestock farmers and to control the raw materials used, the manufacturing process, and the quality of the compound feed produced (Fefac, 2009).

The transport costs of primary ingredients and for the delivery of compound feed largely explain the spatial distribution of feed plants. Decisions regarding where to locate feed plants initially were based on opportunities to access raw materials (cereals and oilseed meals) (Diry, 1985) and proximity to feed demand. In 2003, the spatial distribution of feed plants (Fig. 2) still reflected that of livestock density, especially for pigs and poultry
(Fig. 3). While pigs and poultry are reared in industrial farming systems, the Bretagne and Pays de la Loire regions in western France represent the main locations of feed demand. In 2010, the production of compound feed in these two regions represented $59 \%$ of the overall volumes produced in France. The animal feed sector has been subjected to horizontal economic concentration for the past 15 years. The number of compound feed production units has decreased from 380 in 1999 to 301 in 2009 (Fefac, 2009); small-scale companies died out first (ITP, 2005). During this period, the individual production capacity of the production units increased, helping to compensate the low value-added rate. In 2003, 24 (7\%) factories produced more than a third of overall compound feed production (ITP, 2005).

In the Bretagne and Pays de la Loire regions, the feed companies developed a large production capacity with more than 150,000 tons/year plants (Fig. 4). The high density of livestock in the vicinity (30-40 km radius) of production units and the presence of industrial farming systems (in particular for pigs and poultry) resulted in low delivery costs for these companies. Given their proximity to harbours, the factories located in these regions also could take advantage of opportunities to import raw materials and export feed. In areas of France where animal density is lower, higher delivery costs did not allow the development of large-capacity production units. Companies in these areas tend to specialize more in the production of specific feed (for game, fish, horse, for example) and in packaging adapted for small farms (delivery in bags).

To sum up, the feed industry has undergone deep restructuring over the past fifty years. The local contexts of feed factories varies greatly in France, mirroring the 

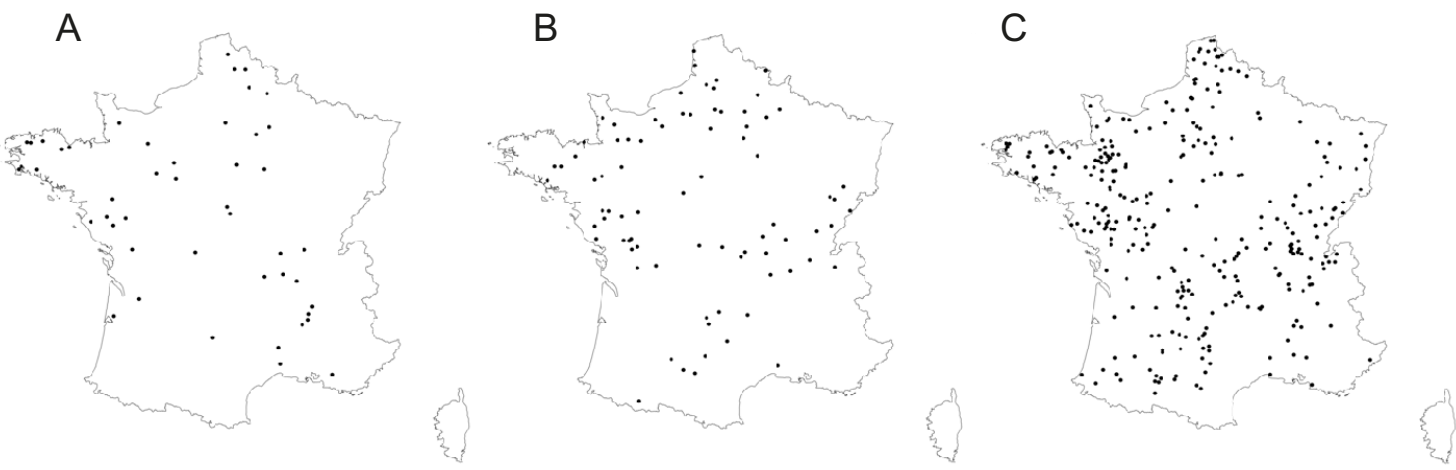

Fig. 2. Location of feed production plants: (A) for pigs and/or poultry, not for cattle $(n=48)$; (B) for cattle, not for pigs and/or poultry $(n=80)$; (C) for cattle and for pigs and/or poultry $(n=317)$. Plants in production between January 1991 and November 2000 (date of the total ban of MBM and by-products in feed for all farm species); data collected for the purpose of the study (AFSSA, 2001).
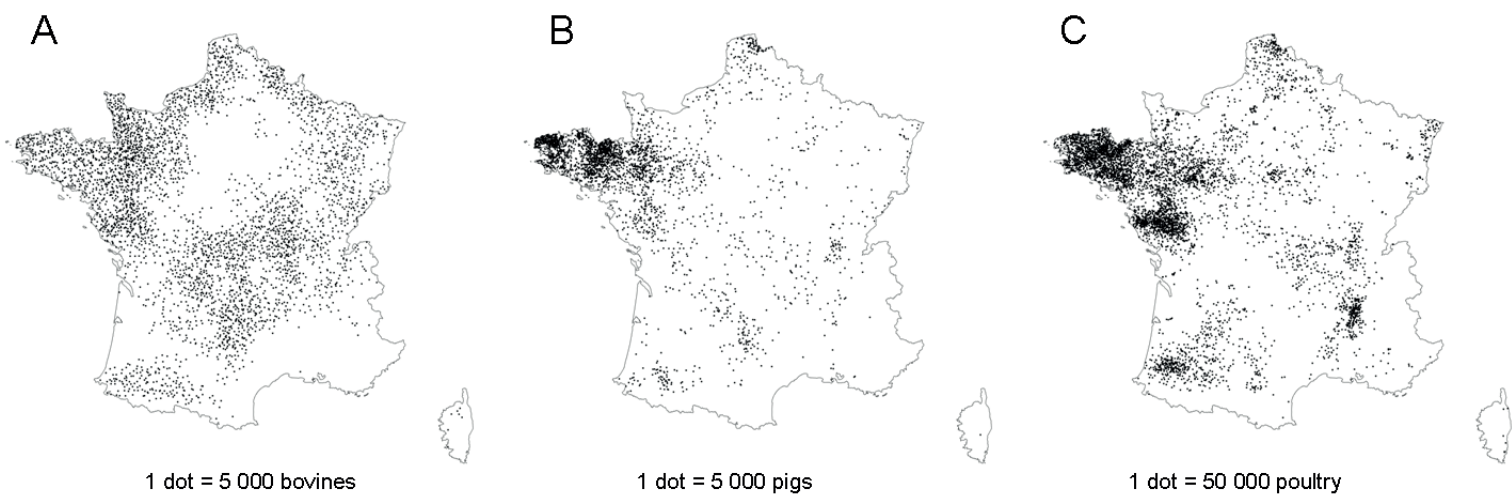

Fig. 3. Spatial distribution of livestock in France: cattle (A), pig (B) and poultry (C). Data from the Agricultural Census 2000 (CD-ROM, edited by Agreste, 251 rue de Vaugirard, 75732 Paris, France).

spatial heterogeneity of animal density, access to raw materials, and export opportunities. The value-added rate for the animal feed industry is low, so massive efforts must be made to limit production costs, including adapting feed formulation to the international market prices of ingredients and limiting transportation costs. In this context, when faced with the need to manage crosscontaminations, the options available to feed manufacturers are quite restricted.

\section{Management of cross-contaminations by feed manufacturers}

Given the spatial distribution of farm animals in France, in the past most feed factories produced feed for both monogastric and ruminant species. Data collected by the Ministry of Agriculture showed that between 1991 and $2000,71 \%$ of the 445 production units were producing feed for both cattle and monogastrics and that only $10.7 \%$ were specialized in ruminant feed. This is consistent with previous reports (AFSSA, 2001). In plants which produced feed for both ruminants and pigs or poultry, processing lines rarely were separated completely (AFSSA, 2001). As a result, most mixed feed factories were potentially exposed to cross-contaminations which may have occurred when parts of the processing lines were used successively for ruminant and monogastric feed, or through the recycling of components coming from unsold monogastric feed in feed for ruminants. The cross-contamination of ruminant feed by MBM initially dedicated to pigs or poultry therefore may have occurred unintentionally even in factories where manufacturers complied strictly with regulations (AFSSA, 2001).

Feed manufacturers have applied different corrective measures to control cross-contaminations. The sequence of feed processing between ruminant and non-ruminant feed was revised to prevent unsafe carry-over of feed containing MBM into ruminant feed. Flush material transferred through the processing line to remove residues also was introduced (Thiebot B. \& Delomez X., Ministry of Agriculture, personal communication). Unfortunately, these strategies did not succeed in controlling cross-contaminations with regard to BSE risk. 


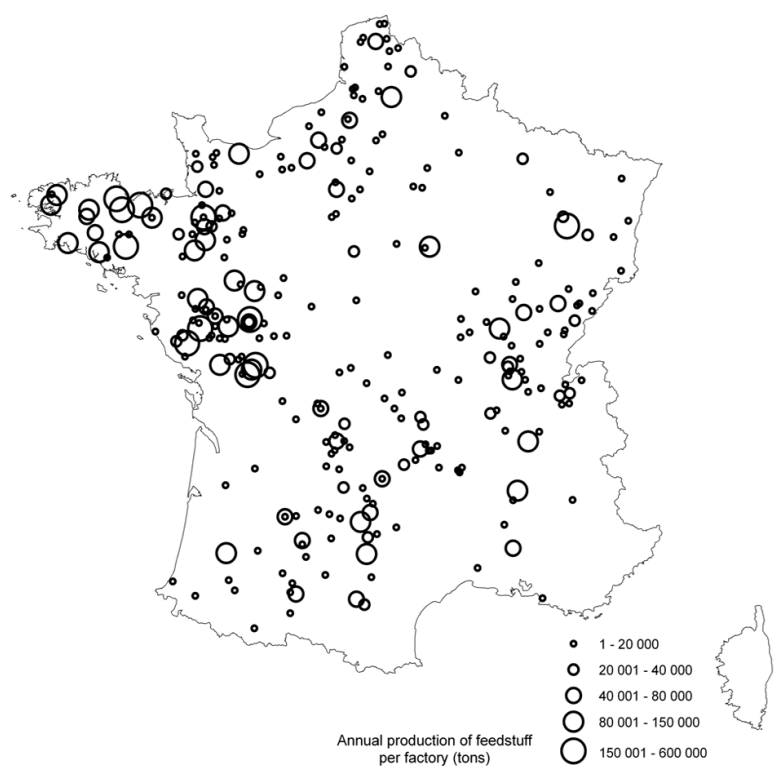

Fig. 4. Volumes of animal compound feed produced by production unit (290 units in production between January 1991 and November 2000). Data collected for the purpose of the study (AFSSA, 2001).

As even negligible volumes of MBM are sufficient to produce risky cross-contaminations, the ultimate solution to the problem of cross-contamination within factories is to completely separate feed processing lines dedicated to monogastric species from those for ruminants. However, this requires production plants to be radically restructured. Two options are possible. The first is to design two separate processing lines within one factory. In this case, new machines sometimes are needed and infrastructure has to be adapted. When corrective measures were introduced, industrialists may have been reluctant to make such investments given the economic context of the sector. The second possibility is to separate the chains for ruminants and non-ruminants into distinct production units. To be financially viable, each production unit needs to produce larger volumes with the best delivery costs. This is possible in areas with a high animal density such as Bretagne. However, in regions with low animal density, the delivery costs would nullify the benefits. In these regions, the specialization of production units would never be possible (Diry, 1985).

The optimal management of cross-contaminations would have involved a complete restructuring of the feed industry, but the economic context in this sector made such change difficult. Feed manufacturers implemented changes but their timing varied greatly depending on their location. Due to the large animal feed market in Bretagne, where animal density was and remains high, animal feed manufacturers were able to quickly implement the necessary changes for the specialisation of the production units. Given the high density of monogastric and ruminant farms, delivery costs were low and each production unit could be profitable even when dedicated to only monogastrics or ruminants. In other regions, the situation was more complex and it probably was not economically feasible to specialize factories. The investment capacity of the large manufacturers located in western France also may have been greater than that of small-scale manufacturers located in areas with sparse livestock farming.

In sum, it is very difficult to handle perfectly the problem of cross-contamination between feed for monogastrics and feed for ruminants, which is complicated by the capacity of contaminated material to infect cattle at a very low dose. Dedicating production units to one species may be a good answer but this only is feasible in regions with high animal densities; creating completely separate production lines in a factory is another option but represents a huge investment in relation to the low valueadded rate of the feed industry.

\section{Discussion and perspectives for the future}

Epidemiological studies as well as a complementary geographical approach based on interviews and the analysis of the historical and economic context of the feed industry provided a rather good understanding of how the BSE epidemic spread through the feed chain, even after the first ban on MBM in feed for cattle. This feed ban did not allow the risk of BSE to be totally controlled, and cases even occurred in animals born after the second ban, which included the removal of SRM from MBM dedicated to the feed of monogastric species. These cases most probably were caused by crosscontaminations between feed for monogastrics and feed for ruminants, either at the feed factory or farm level, notably on farms raising both cattle and monogastric species. These observations were supported by modeling studies of the BSE epidemic that showed a decline of the risk of BSE after the first ban and a reinforced decrease but not complete eradication after the second ban. The epidemic almost stopped when a third and total ban on MBM in feed for all farm animals came into force in 2000, which may be a simple coincidence insofar as the estimated risk already was almost nil when this last measure was implemented.

The fact that the risk had diminished but had not yet been totally controlled prior to the enforcement of the most radical measures is unsurprising when one considers the difficulty of totally controlling cross-contamination in feed factories and the ability of contaminated material to infect cattle at a very low dose. The production process is so intricate on a production line that crosscontaminations can occur at various points and during 
different steps. The two options available to control crosscontaminations may not be economically feasible due to the low value-added rate of the feed industry. Dedicating factories to one species seems to be a feasible option in regions with high animal density and this has been carried out in Bretagne; creating completely separate production lines in a factory is another option but represents an investment that only is profitable if sales can be increased, which depends in part on shipping costs.

The second TSE road map of the European Union (European Commission - Directorate-General for Health \& Consumers, 2010) plans to allow processed animal proteins (PAP), produced from safe products, from pigs in poultry feed, as well as PAP from poultry in pig feed, while maintaining the ban on those products in ruminant feed as well as PAP from cattle in feed for all farm species. However, as yet no test is available that is sufficiently sensitive to detect PAP in feed or to identify the presence of proteins originating from different species in PAP or feed (Efsa, 2011). Morever, organising controls in factories would be difficult given the limited resources currently available to control services. Any change in existing regulations would require perfect tracability of the sources of the primary material used in the production process, including recycled feed returned from farms, as well as a rigorous hazard analysis critical control point (HACCP) approach in factories. Another question that would have to be addressed is how to ensure that farmers raising both monogastrics and cattle do not feed heifers or cows with leftover pig or poultry feed.

In the EU view of relaxing control measures, the risk of BSE is controlled with the conjunction of an almost null prevalence of BSE, combined with two different measures, safe sourcing of products that enter the PAP, and ban of PAP in ruminant feed. Nevertheless, given that i) some BSE cases are still detected from time to time, born after the total ban of MBM in animal feed, ii) atypical BSE was discovered and might be a hazard for Human health, and iii) a perfect compliance of the sanitary rules in abattoir and feed industry might be difficult to achieve in a daily routine and in a context of decreased risk pressure, we consider that the risk of cross-contamination needs to be handled with great caution in the feed industry and at the farm level.

The situation analysed in France can be extrapolated to neighbouring countries in the EU given the similar evolution in BSE trends there following EU regulations (Ducrot et al., 2010), the comparable results of different epidemiological studies on risk factors (Ducrot et al., 2008), and the similar organisation and market structure of the cattle and cattle supply industry. Different lessons can be derived from the results observed. Any change in control measures needs to target both the feed industry and farms since cross-contaminations occur at both levels. The difficult economic context of the feed industry also must be taken into account because the most effective ways to control cross-contamination are not feasible solutions for all actors in the feed industry given their local constraints. There are far fewer BSE cases now than in the nineties when control measures were taken. Consequently, the risk of BSE (or another cattle TSE such as atypical forms of BSE) spreading again to cattle through the feed chain if the problem of cross-contamination is not resolved properly should be lower than it was before. However, it is our collective responsibility to learn from the past and implement a sustainable system that will ensure that such a TSE epidemic and crisis will never happen again.

\section{Acknowledgements}

We thank the feed producers, renderers, technicians from the Chamber of Agriculture, as well as the veterinary practitioners and cattle farmers for their participation in the interviews. We thank the Direction générale de l'alimentation of the French Ministry of Agriculture for supporting the different epidemiological studies, as well as the county veterinary services that collected data from the feed industries and the "Brigade nationale d'enquêtes vétérinaires et phytosanitaires" for their advice. We would like to thank Grace Delobel for her review of the English.

\section{References}

Abrial, D., Calavas, D., Jarrige, N., Ducrot, C., 2005. Poultry, pig and the risk of BSE following the feed ban in France: Spatial analysis, Veterinary Research, 36, 615-628.

AFSSA, 2001. Les risques sanitaires liés aux différents usages des farines et graisses d'origine animale et aux conditions de leur traitement et de leur élimination, Avis de l'Afssa en date du 7 avril 2001 (http:/ / www.vie-publique.fr/documents-vp/ avis_afssa_070401.pdf, consulted May, 3, 2013).

Agreste, 1995. Enquêtes annuelles d'entreprise : industries agroalimentaires, Ministère de l'Agriculture, de l'Alimentation, de la Pêche, de la Ruralité et de l'Aménagement du territoire.

Allepuz, A., López-Quîlez, A., Forte, A., Fernández, G., Casal, J., 2007. Spatial analysis of bovine spongiform encephalopathy in Galicia, Spain (2000-2005), Preventive Veterinary Medicine, 79, 2-4, 174-185.

Beringue, V., Herzog, L., Reine, F., Le Dur, A., Casalone, C., Vilotte, J.-L., Laude, H., 2008. Transmission of atypical bovine prions to mice transgenic for human prion protein, Emerging Infectious Diseases, 14, 12, 1898-901.

Biacabe, A. G., Morignat, E., Vulin, J., Calavas, D., Baron, T., 2008. Atypical bovine spongiform encephalopathies, France, 2001-2007, Emerging Infectious Diseases, 14, 2, 298-300.

Brookes, G., 2001. The EU animal feed sector: protein ingredient use and implications of the ban on use of meat and bonemeal, Brookes West, Canterbury.

Calavas, D., Supervie, V., Morignat, E., Costagliola, D., Ducrot, C., 2007. Complementary approach of data analysis and 
modelling to estimate the pattern of the BSE epidemic: the example of France, Risk Analysis, 27, 1141-1150.

Clauss, M., Sauter-Louis, C., Chaher, E., Pottgiesser, C., Goebel, S., Selhorst, T., Wichmann, H.E., Klee, W., Kienzle, E., 2006. Investigations of the potential risk factors associated with cases of bovine spongiform encephalopathy in Bavaria, Germany, The Veterinary Record, 158, 15, 509-513.

Denny, G.O., Hueston, W.D., 1997. Epidemiology of bovine spongiform encephalopathy in Northern Ireland 1988 to 1995, The Veterinary Record, 140, 302-306.

Diry, J.P., 1985. L'industrialisation de l'élevage en France. Économie et géographie des filières avicoles et porcines, Paris, Ophrys.

Doherr, M.G., Hett, A.R., Rufenacht, J., Zurbriggen, A., Heim, D., 2002. Geographical clustering of cases of bovine spongiform encephalopathy (BSE) born in Switzerland after the feed ban, The Veterinary Record, 151, 467-472.

Dronne, Y., 2003. Avenir du secteur de l'alimentation animale en relation avec les filières végétales, Inra Productions Animales, 16, 5, 333-340.

Ducrot, C., Abrial, D., Calavas, D., Carpenter, T., 2005. A spatio-temporal analysis of BSE cases born before and after the reinforced feed ban in France, Veterinary Research, 36, 839-853, doi: 10.1051/vetres:2007053.

Ducrot, C., Arnold, M., De Koeijer, A., Heim, D., Calavas, D., 2008. Review on the epidemiology and dynamics of BSE epidemics, Veterinary Research, 39, 15, doi: 10.1051/ vetres:2007053.

Ducrot, C., Roy, P., Morignat, E., Baron, T., Calavas, D., 2003. How the surveillance system may bias the results of analytical epidemiological studies on BSE: prevalence among dairy versus beef suckler cattle breeds in France, Veterinary Research, 34, 185-192, doi: 10.1051/vetres:2002065.

Ducrot, C., Sala, C., Ru, G., De Koeijer, A., Sheridan, H., Saegerman, C., Selhorst, T., Arnold, M., Polak, M.-P. Calavas D., 2010. Modelling BSE trend over time in Europe, a risk assessment perspective, European Journal of Epidemiology, 25, $6,411-419$.

Efsa, 2011. Scientific opinion on the revision of the quantitative risk assessment (QRA) of the BSE risk posed by processed animal proteins (PAPs), Efsa Journal, 9, 1, 1947.

Enjalbert, F., 1996. Les farines de viande : intérêts dans l'alimentation des ruminants et réglementation, Le Point Vétérinaire, 28, 61-67.

European Commission - Health \& Consumers, 2010. The TSE Roadmap 2: A strategy paper on Transmissible Spongiform Encephalopathies for 2010-2015, European Union, Brussels.

Fefac, 2009. Feed and Food Statistical Yearbook 2009.

Hasha, G., 2002. Livestock Feeding and Feed Imports in the European Union - A Decade of Change, Electronic Outlook Report No. FDS-0602-01, U.S. Department of Agriculture, Economic Research Service (www.ers.usda.gov/publications/ fds/july02/fds0602-01/).

Hoinville, L.J., Wilesmith, J.W., Richards, M.S., 1995. An investigation of risk factors for cases of bovine spongiform encephalopathy born after the introduction of the feed ban, The Veterinary Record, 136, 312-318, doi:10.1136/ vr.136.13.312.
ITP, 2005. Aliments industriels 1994-2004 : de nombreux défis, Baromètre Porc, 337, 1-8.

Jarrige, N., Ducrot, C., Cazeau, G., Morignat, E., La Bonnardière, C., Calavas, D., 2007. Case-control study on risk factors for BSE cases born after the feed ban in France, Veterinary Research, 38, 505-516.

Kamphues, J., Zentek, J., Oberthur, R.C., Flachowsky, G., Coenen, M., 2001. Risk assessment for animal derived feedstuffs as vectors for bovine spongiform encephalopathy (BSE) in Germany. Part I: Comparative risk assessment for animal derived feedstuffs, Deutsche Tierarztliche Wochenschrift, 108, 283-290.

Lapierre, O., Pressenda, F., 2002. Adaptation des stratégies d'approvisionnement des filières animales en matières premières riches en protéines, Oléagineux, Corps gras, Lipides, 9, 2, 86-91.

Mouillet, Y., 2003. Désintensification et autonomie en protéines, Les Dossiers de l'Environnement de l'Inra, 24, 125-128.

Paul, M., Abrial, D., Jarrige, N., Rican, S., Garrido, M., Calavas, D., Ducrot, C., 2007. Bovine Spongiform Encephalopathy and Spatial Analysis of the Feed Industry, Emerging Infectious Diseases, 13, 6, 867-872.

Quinqu, M., 1989. Perspectives de l'industrie française de l'alimentation animale. Thèse de doctorat d'Université, Rennes I.

Rude, J., Meilke, K., 2000. Implications of CAP Reform for the European Union's Feed Sector, Canadian Journal of Agricultural Economics, 48, 4, 411-420.

Sala, C., Morignat, E., Ducrot, C., Calavas, D., 2009. Modelling the trend of bovine spongiform encephalopathy prevalence in France: use of restricted cubic spline regression in ageperiod-cohort models to estimate the efficiency of control measures, Preventive Veterinary Medicine, 90, 1-2, 90-101.

Schwermer, H., Heim, D., 2007. Cases of bovine spongiform encephalopathy born in Switzerland before and after the ban on the use of bovine specified risk material in feed, The Veterinary Record, 160, 3, 73-77, doi:10.1136/ vr.160.3.73.

Supervie, V., Costagliola, D., 2004. The unrecognised French BSE epidemic, Veterinary Research, 35, 349-362.

Supervie, V., Costagliola, D., 2005. Modelling of the French BSE epidemic: use the screening test data, in Francis, A.R., Matawie, K.M., Oshlack, A., Smyth, G.K., (Eds) Statistical Solutions to Modern Problems, Proceedings of the 20th International Workshop on Statistical Modelling, Sydney, Australia, 453-460.

Wells, G.A.H., Konold, T., Arnold, M.E., Austin, A.R., Hawkins, S.A.C., Stack, M., Simmons, M.M., Lee, Y.H., Gavier-Widen, D., Dawson, M., Wilesmith, J.W., 2007. Bovine spongiform encephalopathy: the effect of oral exposure dose on attack rate and incubation period in cattle, Journal of General Virology, 88, 4, 1363-1373.

Wilesmith, J.W., 1996. Recent observations on the epidemiology of bovine spongiform encephalopathy, in Gibbs, C.J. (Ed.), Bovine Spongiform Encephalopathy: The BSE Dilemma, Springer Verlag, New York, 45-55.

Wilesmith, J.W., Ryan, J.B.M., Atkinson, M.J., 1991. Bovine spongiform encephalopathy: epidemiological studies on the origin, The Veterinary Record, 128, 199-203, doi:10.1136/ vr.142.5.103. 